PERM JOURNAL OF PETROLEUM AND MINING ENGINEERING ВЕСТНИК ПНИПУ. ГЕОЛОГИЯ. НЕФТЕЕАЗОВОЕ И ГОРНОЕ ДЕЛО

ISSN 2224-9923

Volume/ ToM 16 №2, 2017

http://vestnik.pstu.ru/geo

УДК 553.982 .2

Article / Статья

(C) PNRPU / ПНИПУ, 2017

\title{
CHAYANDINSKOYE FIELD IS THE PROJECT OF NEW TECHNOLOGIES IMPLEMENTATION IN EAST SIBERIA
}

\section{Aleksei V. Davydov, Aleksandr V. Pogretckii, Oleg A. Smirnov ${ }^{1}$, Andrei V. Lukashov', Andrei P. Pravdukhin', Arkadii R. Kurchikov', Vladimir N. Borodkin ${ }^{1,3}$}

Gazprom Geologorazvedka LLC (70 Gertcen st., Tyumen, 625000, Russian Federation)

${ }^{1}$ INGEOSERVICE LLC (211 Respubliki st., Tyumen, 652019, Russian Federation)

${ }^{2}$ West-Siberian branch of the Institute of Oil and Gas Geology and Geophysics named after A.A. Trofimuk of Siberian Branch

of the Russian Academy of Sciences (56 Volodarskogo st., Tyumen, 625000, Russian Federation)

${ }^{3}$ Tyumen Industrial University (211 Respubliki st., Tyumen, 652019, Russian Federation)

\section{ЧАЯНДИНСКОЕ МЕСТОРОЖДЕНИЕ - ПРОЕКТ ВНЕДРЕНИЯ НОВЫХ ТЕХНОЛОГИЙ В ВОСТОЧНОЙ СИБИРИ}

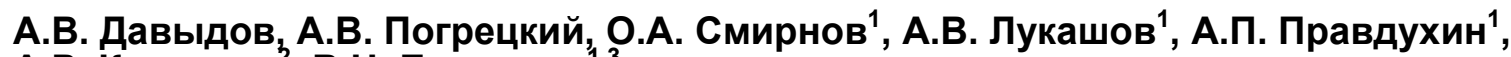 A.P. Курчиков ${ }^{2}$, В.Н. Бородкин}

ООО «Газпром геологоразведка» (625000, Россия, г. Тюмень, ул. Герцена, 70)

${ }^{1}$ ООО «ИНГЕОСЕРВИС» (652019, Россия, г. Тюмень, ул. Республики, 211)

${ }^{2}$ Западно-Сибирский филиал Института нефтегазовой геологии и геофизики им. А.А. Трофимука СО РАН (625000, Россия,

г. Тюмень, ул. Володарского, 56)

${ }^{3}$ Тюменский индустриальный университет (652019, Россия, г. Тюмень, ул. Республики, 211)

Received / Получена: 30.03.2017. Accepted / Принята: 10.05.2017. Published / Опубликована: 30.06.2017

Key words:

Chayandinskoye oil and gas condensate field, Botuobinsk formation, Khamakinsk formation, Talakh formation, wide-azimuth observation system, fracturing, azimuthal velocity analysis, azimuth AVO-analysis (AVAZ), anisotropic inversion, anisotropic depth migration, high-resolution seismic survey, structural and tectonic model, 3D seismic survey, seismic attributes, elastic impedances, attribute cubes.
Modern level of study of structure of Chayandinskoye oil and gas condensate field is characterized by implementation of 3D seismic survey, carried out using a rich azimuth seismic survey system with a fold of 240. Complex seismic and geological conditions within this part of Eastern Siberia dictate high requirements to quality of field 3D seismic operations. A geological section of an area of operations is characterized by Lower Proterozoic formations of crystalline basement and Vendian, Cambrian, Jurassic, Quaternary deposits of the sedimentary cover. The main role in structure of the sedimentary cover is played by clastic and carbonate deposits of Vendian and halogencarbonate formations of Cambrian Period. Productive part of a section refers to Botuobinsk, Khamakin and Talakh suits and is characterized by a very complex structure of natural reservoirs. Study of productive section structure is caused by need to prepare a field for production drilling and its subsequent development. In order to reveal features of structure of productive part of a section in a region with complex seismic and geological conditions, migration is used up to the summation in the deep region. Wide-azimuth observation system is aimed to study the most important challenges of medium structure such as direction and nature of change in fracture, study of azimuthal anisotropy of velocity characteristics of section and identification of characteristics of elastic properties change. Base technologies to study anisotropy of geological section properties are adapted and introduced into seismic exploration technique. They are as follows: 1) a method based on study of geometric attributes; 2) azimuthal analysis of velocities; 3) azimuth AVO-analysis (AVAZ); 4) anisotropic inversion. Based on results of processing and complex interpretation of seismic data of MOGT-3D works at the Chayandinskoye oil and gas condensate field the most important information about geological structure of sedimentary cover deposits and productive section was obtained. That allowed to significantly clarifying concept of structure of productive formations and geological development of this
distribution of reservoirs and evaluating reserves with considered new built structural and tectonic model.

Современный уровень изучения строения Чаяндинского нефтегазоконденсатного месторождения характеризуется внедрением сейсморазведки 3D, выполненной по технологии полноазимутальной системы наблюдений с кратностью 240 Сложные сейсмогеологические условия в пределах данной части Восточной Сибири диктуют повышенные требования к качеству проведения полевых сейсморазведочных работ $3 \mathrm{D}$. Геологический разрез района работ характеризуют нижнепротерозойские образования кристаллического фундамента и вендские, кембрийские, юрские, четвертичные отложения осадочного чехла. Основную роль в строении осадочного чехла играют терригенно-карбонатные отложения венда и галогенно-карбонатные образования кембрия. Продуктивная часть разреза относится к ботуобинскому, хамакинскому и галогенно-карбонатные образования кембрия. Продуктивная часть разреза относится к ботуобинскому, хамакинскому и талахскому горизонтам и характеризуется очень сложным строением природных резервуаров. Изучно бурению продуктивной части разреза продиктовано необходимостью подготовки месторождения к эКсплуатационному бурению и Последующей его разработки. С целью выявления особенностей строения продуктивной части разреза в регионе со широкоазимутальная система наблюдения направлена на изучение важнейших вопросов строения среды: направление и характер изменения трещиноватости, изучение азимутальной анизотропии скоростных характеристик разреза, выявление характеристик изменения упругих свойств. Адаптированы и внедрены в практику сейсморазведочных работ основные технологии изучения анизотропии свойств геологического разреза: 1) метод, основанный на изучении геометрических атрибутов; 2) азимутальный анализ скоростей; 3) азимутальный AVO-анализ (AVAZ); 4) анизотропная инверсия. По результатам обработки и комплексной интерпретации сейсморазведочных материалов работ МОГТ-ЗД на Чаяндинском нефтегазоконденсатном месторождении получена важнейшая информация о геологическом строении отложений осадочного чехла и продуктивной части разреза, что позволило значительно уточнить представление о строении продуктивных горизонтов и геологическом развитии данной территории, более адекватно определить пространственное распространение коллекторов и оценить запасы с учетом вновь построенной структурно-тектонической модели.

Aleksei V. Davydov - Chief executive officer (tel.: +007 34525409 54, e-mail: office@ggr.gazprom.ru).

Aleksandr V.Pogretckii (Author ID in Scopus: 56358996200) - Head of the Department of Geophysical Work and Survey Organization (tel.: +007345 2540946, e-mail: a.pogretskiy@ggr.gazprom.ru). Oleg A. Smirnov (Author ID in Scopus: 56400448200) - PhD in Geological and Mineralogical Sciences, Chief Geologist (tel.: +007 345 221 52 95, e-mail: osmirnov@ingeos.info).

The contact person for correspondence.
Andrei V. Lukashov (Author ID in Scopus: 6701815561) - Chief executive officer (tel.: +007 34522152 95, e-mail: info@ingeos.info)

Andrei P. Pravdukhin - Head of the Department of Seismic Survey Data Processing (tel.: +007 34522152 95, e-mail: apravduh@ingeos.info).

Arkadii R. Kurchikov (Author ID in Scopus: 6602684129) - Doctor of Geological and Mineralogical Sciences, Professor, Director (tel.: +007 3452465827 , e-mail: niigig ku@sibtel.ru).

Vladimir N. Borodkin (Author ID in Scopus: 36652408900) - Doctor of Geological and Mineralogical Sciences, Chief Specialist (tel.: +007 345 244 43 58, e-mail: info@ingeos.info) Давыдов Алексей Владимирович - генеральный директор (тел.: +007 34525409 54, e-mail: office@ggr.gazprom.ru).

Погрецкий Александр Владимирович - начальник отдела по организации геофизических работ и исследований (тел.: + 0073452540946 , e-mail: a.pogretskiy@ggr.gazprom.ru). Смирнов Олег Аркадьевич - кандидат геолого-минералогических наук, главный геолог (тел.: +007 34522152 95, e-mail: osmirnov@ingeos.info). Контактное лицо для переписки. Смирнов Олег Аркадьевич - кандидат геолого-минералогических наук, главный геолог (тел.: + +007345 221 5295 , e-m
Лукашов Андрей Викторович - генеральный директор (тел.: +007 3452215295 , e-mail: info@ingeos.info). Правдухин Андрей Петрович - начальник отдела обработки материалов сейсморазведки (тел.: +007 34522152 95, e-mail: apravduh @ingeos.info). Курчиков Аркадий Романович - доктор геолого-минералогических наук, профессор, директор (тел.: +007 3452465827 , e-mail: niigig ku@sibtei.ru). 


\section{Introduction}

The group of companies of Gazprom PJSC owns following license areas on the territory of the Republic of Sakha (Yakutia) such as Chayandinskoye, Verkhne-Vilyuchanskoye, TasYuryakhskoye, Sobolokh-Nedzhelinskoye, Srednetungskoye and Tympuchikanskoye. The most significant is Chayandinskoye giant field of hydrocarbon reserves. Chayandinskoye oil and gas condensate field is located in the southwestern part of the Republic of Sakha (Yakutia) and belongs to Leno-Tunguska oil and gas province, NepskoBotuobinsk oil and gas region, Botuobinsk oil and gas bearing area. The field was discovered in 1980. Vendian deposits such as Botuobinsk, Khamaki and Talakh reservoirs are productive. The State Register of Mineral Reserves of Russian Federation mineral deposits contain reserves of oil, gas, condensate and helium. Since 2009 Gazprom PJSC has been conducting work on additional exploration of the field. Gazprom Geologorazvedka LLC is an operator of geological exploration [1]. Scientific, technical, geological and geophysical works are preformed by specialists from such companies as Gazprom Geologorazvedka engineering and technical center, CNIP GIS LLC, Gazprom VNIIGAZ LLC and INGEOSERVICE LLC.

Today, the field is covered by a $2 \mathrm{D}$ seismic survey network $(1500 \mathrm{~km}), 6,300 \quad \mathrm{~km}^{2}$ of 3D seismic survey is performed with a subsurface area of $6,980 \mathrm{~km}^{2}$. From 2013 a modern level 3D survey is implemented on the field. It is performed using a technology of a rich azimuth observation system with a multiplicity of 240 (Fig. 1).

Processing of field seismic material was carried out in INGEOSERVICE LLC in Geocluster processing system version 5000 of CGG Veritas company.

\section{Goal statement}

It was stated that 3D seismic had to study in details geological structure and a structural and tectonic model of pay section of reservoir of Chayandinskoye field, clarify geometry of tectonic blocks, zone and determine zones of rock fracturing, predict rock lithotypes and reservoir properties of a section. Solution of such a range of tasks is impossible without use of modern methodical and technological means from supervision of fieldwork to processing and interpretation.

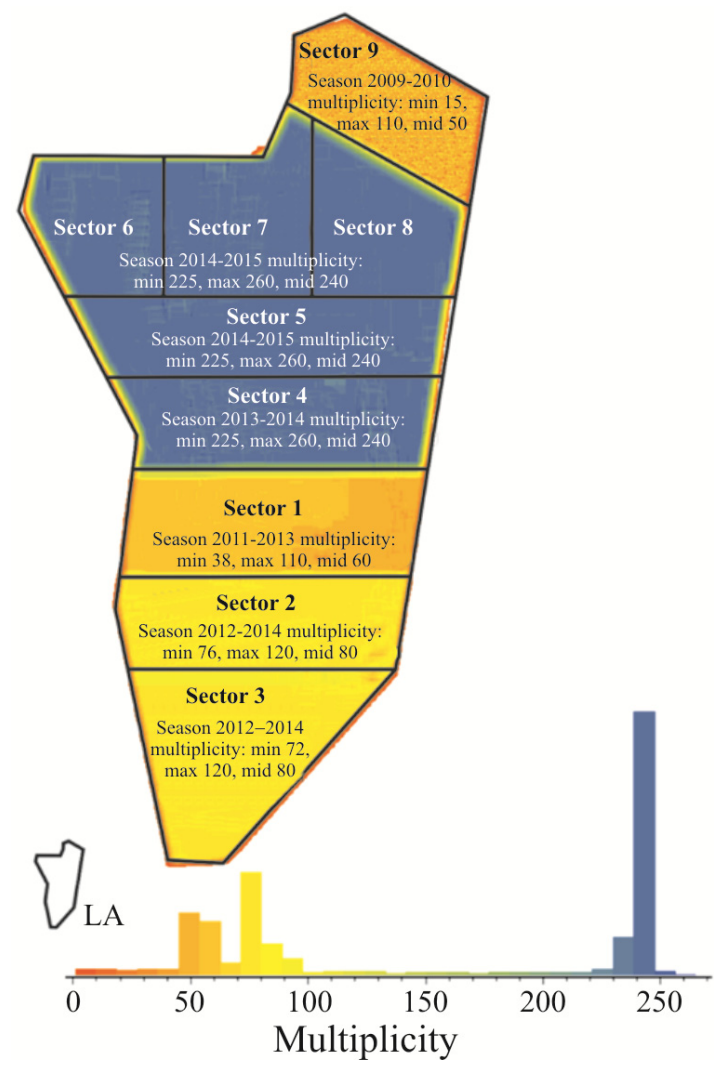

Fig. 1. Map of multiplicity of seismic works

A big number of works of specialists have been devoted to studying features of structural and tectonic structure and conditions of formation of hydrocarbon traps in clastic Vendian deposits [2-11].

The main seismic and geological features of oil and gas potential layers in Eastern Siberia are age of deposits and, as a consequence, high degree of secondary rock trasformations. Age of rocks of a plateau Vendian-Cambrian stage of the sedimentary cover is $500-680 \mathrm{Ma}$, sediments of the pre-Riphean stage of the sedimentary cover are 950-1500 Ma. This explains high interval velocity 
of propagation of reflected seismic waves in a given interval.

Complex spatial arrangement of predominantly clastic oil and gas complexes and features of their correlation with overlapping higher-velocity saliferous deposits cause an objective difficulty in studying their structure from seismic data. A section of the sedimentary cover is divided into following contrasting velocity zones:

1. Halogen-carbonate Cambrian part and carbonate deposits of Vendian where the average velocity is $4700-5700 \mathrm{~m} / \mathrm{s}$.

2. The Vendian clastic deposits where the average velocity is $3700-4500 \mathrm{~m} / \mathrm{s}$.

3. Riphean deposits with medium speed 5700 $6000 \mathrm{~m} / \mathrm{s}$.

The upper part of a section in the northern part of Chayandinskaya area is represented by lowspeed clastic deposits of the Bordon suite where reservoir velocities are in the range of 1500-3500 $\mathrm{m} / \mathrm{s}$. Thickness of sediments within the area is not constant. Paleodepression in the north is filled with a thickness of clastic sediments of up to $295 \mathrm{~m}$ (wells 321-60), in the southern part wells have small pay thickness 2-70 m (wells 321-72 and 321$72 \mathrm{~m}$ respectively). In conditions of inclined multispeed rocks a lateral velocity gradient is observed in the upper part of the section, which is reflected in functions of $V_{\mathrm{av}}(H)$ versus $H\left(T_{0}\right)$.

Halogen-carbonate stratum of rocks occupy the upper part of the sedimentary cover and is composed by alternating layers of salts and dolomites. These deposits differ sharply in terms of acoustic characteristics both from above clastic rocks and from below productive thickness of clastic Vendian deposits. They are well maintained over a large area. As a consequence, maintained reflecting horizons form both single and multiple and partially multiple waves.

Productive Vendian clastic complex, to which most of oil and gas fields of the Siberian platform is related, is located in the lower part of the plate stage of the sedimentary cover. The complex is composed of finely interbedded rock associations and is characterized by a substantial facies variability in the same age structures. There are almost no regionally constant reflecting boundaries in its volume.

\section{Anisotropic pre-stack depth migration}

The application of pre-stack migration in a deep region has proved itself as an efficient technique in various regions with complex seismic and geological conditions. Thanks to large computation power it became possible to implement algorithms for deep migration, both isotropic and anisotropic. Anisotropic migration makes it possible to obtain an image in depth scale, which corresponds to actual depths. This is achieved by introducing the anisotropy parameters $\delta$ and $\varepsilon$ into the algorithm. A refinement of a depth-velocity model and anisotropy parameters was carried out using tomographic inversion. Migrated seismograms on a deep scale were used to obtain a stackcube on a deep scale, as well as a stack cube that was recalculated into a time scale for comparison with result of time pre-stack migration.

A comparison of results of time migration and anisotropic depth migration in the time domain is presented in Fig. 2 and shows an improvement in traceability of seismic horizons and, most importantly, at an interval of the foundation roof.

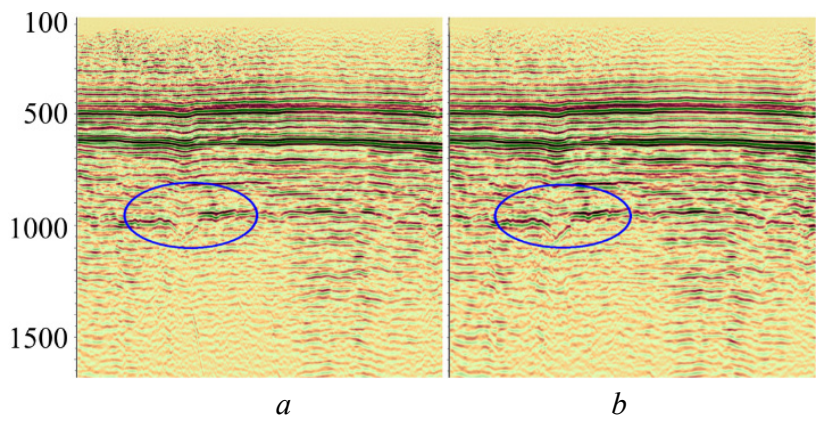

Fig. 2. Comparison of results: $a-$ after time migration; $b-$ after anisotropic depth migration

All this reflect robustness and stability of executed migration reforms.

The main result of processing is production of migrated cubes and seismograms of high quality while maintaining true ratio of amplitudes and 
speed characteristics. As a result, qualitatively new information was obtained due to the following technological and methodical methods:

- application of interference cancellation procedures made it possible to achieve a high signal-to-interference ratio both in seismograms and in the cube;

- application of procedures of correction of static corrections allowed to compensate their influence on a seismic image and to increase quality of summation;

- application of time (PSTM) and pre-stack depth migration (PSDM) provided a correct display of inclined reflecting boundaries in a wave field and transformation of diffracted waves; as a result elements of geological structure became more clear;

- results of migration allow to reveal features of geological structure on a deep scale.

Received seismic materials allowed to solve a large range of scientific and applied issues such as clarifying the structural-tectonic model of the field, detailing the geological structure of the productive part of the section in space between wells, justifying the establishment of new wells and dividing the fracture.

\section{Specification of a structural-tectonic model of the field}

Chayandinskoye oil and gas condensate field is characterized by a complex geological structure. According to an officially accepted geological model it is divided into tectonic blocks such as Northern, Southern I and II, Samanchak. Fundamental differences in understanding of tectonic structure of the field are seen in Fig. 3.

A previously accepted tectonic model included a system of faults of submeridional, north-western and north-eastern strike, dividing the territory into blocks [11] such as Northern, Southern and Samanchak. A newly obtained fault-block model differs greatly from the previously adopted one.

Mapping of tectonic disturbances was carried out on the basis of following set of methodical techniques such as detection of the vertical displacement of in-phase axes on time seismic sections and presence of local anomalies of intensity of reflected waves of the linear strike, control of attenuation and disturbance of dynamics of intensity of reflected waves, analysis of seismic attributes such as cubes of coherence, angles of inclination of surfaces of seismic horizons.

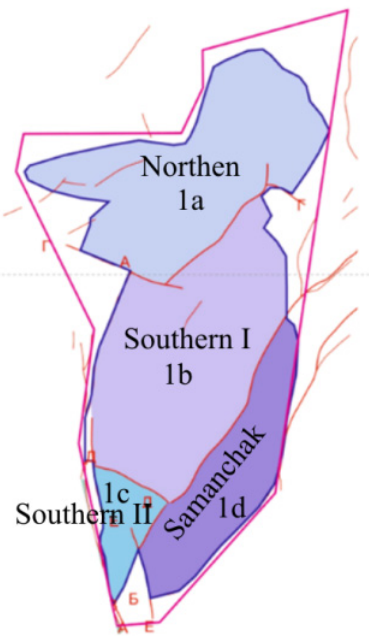

$a$

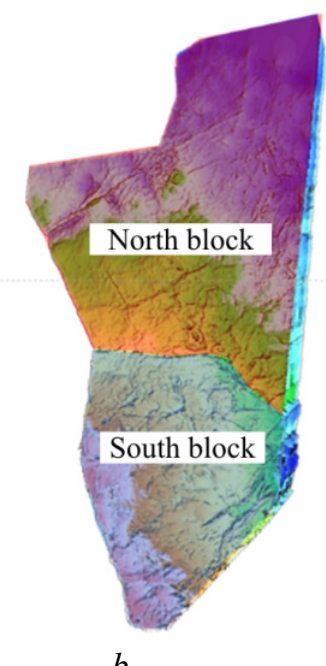

b
Fig. 3. Comparison of tectonic models, newly obtained $(b)$ and previously assumed $(a)$

Analysis of a wave pattern showed that all structural floors of the sedimentary cover are subject to tectonic dislocations. On the background of graben-like narrow directional fault zones that limit tectonic blocks, many elements of local lowamplitude tectonics are traced. Probably, multiple and multidirectional tectonic rearrangements contributed to the wide development of macro- and micro-complexity.

Analyzis of the seismic cube in the interval of 1.5-3.5 $\mathrm{s}$ there are bodies of irregular shape with steep slope are found in foundation body. According to our assumption, those bodies belong to batholiths, which took root in the early stages of formation and evolution of the Siberian platform. It is clear that bodies similar to batholiths are centers of gravitational and magnetoactive masses.

Another important conclusion concerns causal relationship between the origin of deep faults, their roots and extent. A demonstration of the results of interpretation of a wave pattern and reconstruction of the deep structure of a basement are shown in Fig. 4. 


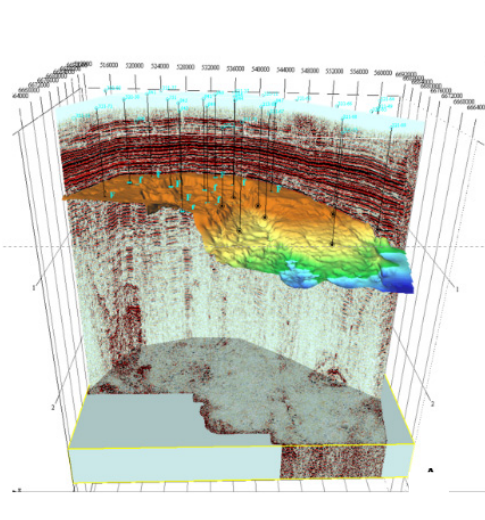

$a$

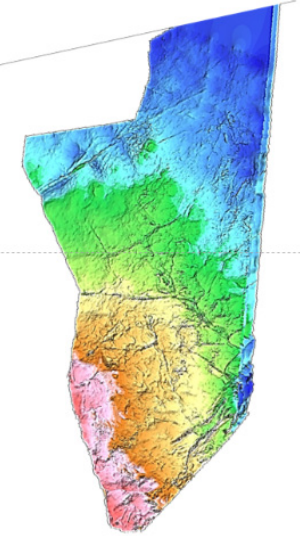

$b$
We believe that a block tectonics mechanism is inseparably linked with geological bodies of deep occurrence, which on the background of timevarying tectonic stresses influenced and possibly determined the mechanism of nucleation, configuration, morphology, system of tectonic discontinuities displacements and shifts.

We propose the following possible mechanism of formation of the fault-block model of the Chayandinskoye field.

Fig. 5 shows a diagram of the interpretation of tectonic stresses, a diagonal system of cracks, which gives good explanation of geometry and configuration of tectonic disturbances by comparing the fracture pattern shown on the map of surface dip angle attribute (DIP).

Fig. 4. Established link of fault tectonics with deep structure of the basement: $a-3 D$ cube section; $b-$ axonometry of the surface of Botuobinsk horizon
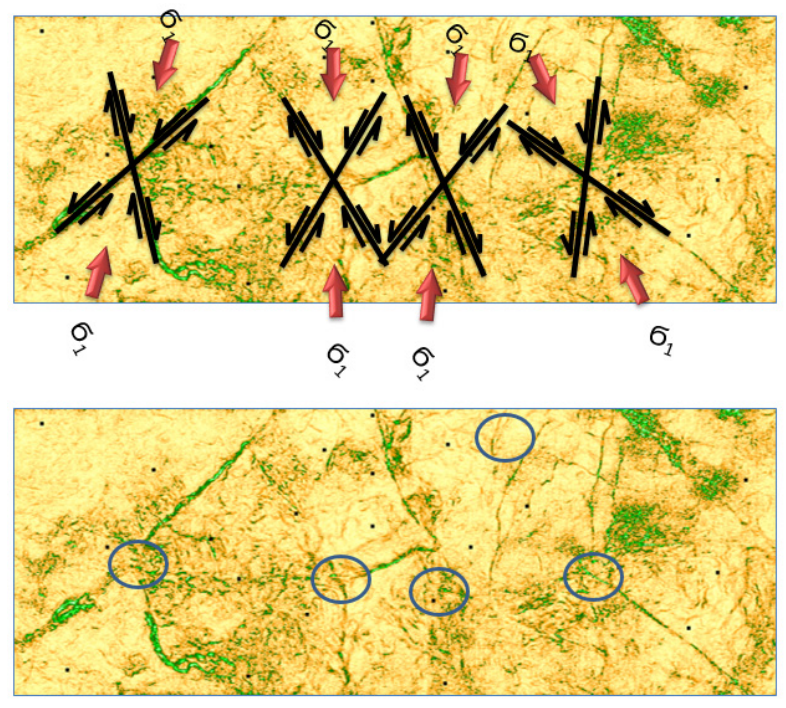

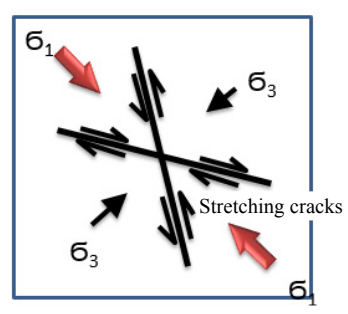

Direction of development of

cracks for the case of a homogeneous medium

Nodes of tectonic stresses

Fig. 5. Application of the theory of formation of cracks to the fault-block model of the field: $\sigma_{1}-$ maximum horizontal stresses; $\sigma_{3}-$ minimum horizontal stresses

To our mind, the scheme of stress location given above proves that the most important directions of compression vectors are from the north and south with formation of characteristic diagonally located planes of disturbances.

\section{Mechanism of fault tectonics formation at the interval of productive horizons}

Many researchers have suggested the formation of hydrocarbon deposits in the Nepsko-Peleduysky arch of the Nepa-Botuoba anteclise under the influence of vertical fluid migration and that activated fault systems of the north-north-east and north-north-west generations played significant role in that $[4,6,7,9,10,12,13]$.

Such systems were activated in the Late Permian and post-Cretaceous epochs, respectively [12]. In the opinion of the authors, activation processes contributed both to formation of deposits in a botanobin horizon of the Vendian, reorganization and partial destruction of zones of oil and gas accumulation of earlier generations in the underlying terrigenous deposits of the Vendian. Stretch cracks are potentially capable of being 
conductors for vertical migration of hydrocarbons. It is possible to say that there were generated zones of decompression and unloading within the Chayandinskoye field which led to hydrodynamic fluid communication between each other and flow of hydrocarbons in a direction down upwards along the fractures of tension and failure.

Another important observation for understanding of the tectonic model of the field is a well-distinguishable crater-like shape along the basement roof (Fig. 6).

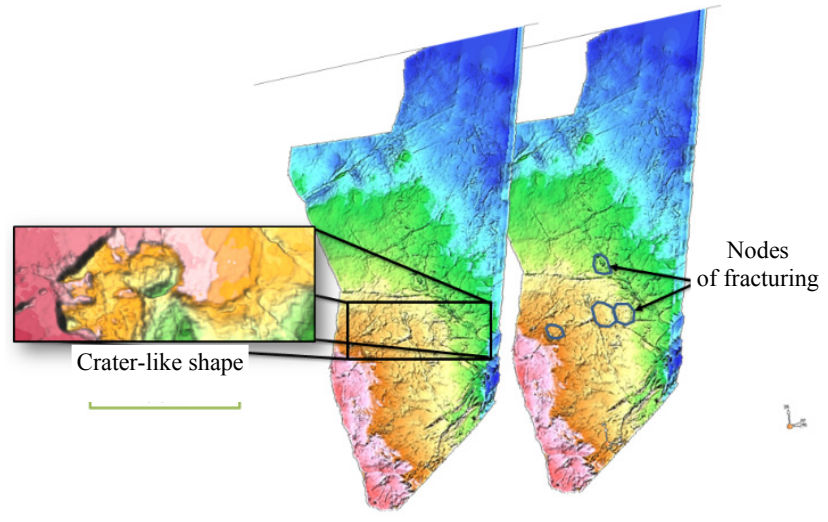

Fig. 6. Nodes and zones of generation of faults and cracks in the roof of the foundation

Such a shape similar to oval does not fit into geometry of the appearence of cracks, ruptures and chips of a low-elastic medium. Attention to this structural form is caused by strong influence on all overlying structural surfaces of different ages. Today, there are three hypotheses that allow to explain the origin of such a rare crater-like shape on the basement surface: 1) an explosion tube; 2) an astroblem; 3) an annular crack - a cylindrical crack of detachment.

We assumed that this round shape is comparable to an explosion tube, which is developed in the territory of Yakutia.

The fact that an explosion tube is formed (or accompanies) and is located in a depocenter zone of a block-fault system proves it. For today, the tectonophysical aspects of formation have been well studied due to their accessibility for full-scale measurements and can serve as an analogue of such artifacts. The second hypothesis of the formation of such structural forms is an astrobleme, which was formed as a result of fall of a cosmic body.

\section{Specification of a geological model of reservoir pay section}

Results and materials of 3D seismic data allow to clarify a geological model of the structure of productive reservoirs in space between wells.

Botuobinsk productive interval is the main object of preparation of hydrocarbon reserves in Nepsko-Botuobinskoye oil and gas area, therefore its distribution, lithological composition, reservoir properties and oil and gas content have been thoroughly studied $[1,11,14]$.

The Botuobinsk productive interval is stratigraphically confined to predominantly sandy lower subcrop of Buka suite of the Iktekh Vendian series. The Buka suite is divided into two subcomponents such as the lower clastic and the upper carbonate.

Lower subsuite (Vbk1) is composed predominantly by sandstones of light gray, to white, quartz, less often feldspar-quartz, and is heterogeneous. Thickness of the subordinate is up to $40 \mathrm{~m}$. Botuobinsk pay interval is distinguished in the volume of the Lower Buka subsuite. Inflows of gas and oil were received from it at the Chayandinskoye field. Upper subsuite (Vbk2) is composed of dolomites, anhydrite-dolomites, interbeds of dolomite marls and mudstones, less often siltstones and sandstones. Thickness of the subsuite is $17-107 \mathrm{~m}$. Total thickness of Buka suite is $28-150 \mathrm{~m}$. Thickness of Botuoba pay interval on the Chayandinskaya area varies from the first meters to $26.6 \mathrm{~m}$.

Distribution of effective thicknesses of the Botuobinsk productive formation is similar to the distribution of total power in particular they reach their maximum values in the center of a propagation band more than $20 \mathrm{~m}$ in the Chayandinskoye (wells 321-07, 321-14) and $39 \mathrm{~m}$ in the Besyuryakhskaya (wells 340-2) areas. They regularly decrease to zero at the boundaries of wedging. 
Botuobinsk horizon is represented by sandstones with subordinate interbeds of siltstones. Sandstones of Botuobinsk productive interval are predominantly quartz, more rare - feldspar and quartz composition, well-sorted fine-grained, medium-grained, rarely coarse-grained differences predominate. In the plantar part of the interval there are interlayers of argillites and aleuros, have thickness mostly from the first millimeters to several centimeters. Only in separate wells the sandstones of the lower part of the Botuoba interval are replaced by intercalation of mudstones, sandstones and siltstones (wells 321-19, 321-2, $847,849)$.

Sandstones have very good reservoir properties in the central part of the strip. Their open porosity varies within the limits of $12-26 \%$, permeability $55-4650 \mathrm{mD}$. Reservoir properties of sandstones deteriorate in the central part of the strip (open porosity - up to 3-10\%, permeability - up to 1-5 mD). Reservoirs of the III class prevail at the Chayandinskoye field. The maximum oil rate of $55 \mathrm{~m}^{3} /$ day was obtained at wells 321-07, gas rate of 574 thousand $\mathrm{m}^{3} /$ day was obtained at wells 321-5.

The Botuobinsk productive interval is covered by a thick (about $40 \mathrm{~m}$ ) dolomite of the upper subordinate of the Buka suite, which is substantially anhydrited in the lowest part (10-15 m). Anhydrite dolomites are the upper regional cap rock.

At the moment, there are two main points of view on the conditions of formation of the Botuobinsk interval. The first point of view is that the sandstones of the Botuobinsk interval were formed as a result of early transgression, accompanied by erosion of dolt formations and accumulation of more sorted material in zones of temporary stabilization of coastlines. This hypothesis is supported by A.N. Dmitrievsky and others. Researchers got to such conclusion due to results of an analysis of the facial substitution of the Botuobinsk interval into facial analogues. Authors of the second point of view [15] believe that the Botuobinsk interval is a large system of bar bodies. This view is based on a detailed core study, detailed cross-well correlation and lithofacies interpretation of sediments studied. For example, in the opinion of O.V. Ivchenko [14] the system of sedimentation of the Botuobinsk interval allows to pick facies of silt and sandy-silt sediments that switch into pre-beach and transitional zones. The author fairly concludes that potential productivity of the wells depends on their facial affiliation. The most productive sediments are located within sediments of the upper part of a coastal slope and deposits of the lower beach and the upper pre-beach zone (facies of silt and siltsand deposits and facies of coastal slope). According to the author, the best reservoir properties are found on a shore slope.

According to L.D. Kolotushchenko [13], the deposits of the Botuobinsk interval are formed in the subaqua zone of low or normal salinity under conditions of relative stabilization of sea level. Land areas such as Mirninsky, Nizhnechonsky, Peleduisky paleo domes were the source of transportation. In the coastal part of the ancient sea, systems of accumulative bar bodies were formed. In our opinion, the last of the above described points of view (according to L.D. Kolotushchenko [13]) most fully explains the conditions of formation of Botuobinsk interval deposits.

Khamakin productive interval stratigraphically confined to a predominantly sandy pack of the upper part of the Parsh suite. It is studied by deep drilling within the Nepa-Botuoba oil and gas area only $[1,10,11]$.

The regional zone of development of the interval is stretched towards the south-west-northeast. Length of the zone is more than $200 \mathrm{~km}$, width is $85 \mathrm{~km}$. The maximum effective thickness of reservoirs (up to $34 \mathrm{~m}$ ) is found in the Chayandinskoye field. Maximal total thickness of the interval (from 25 to $100 \mathrm{~m}$ and more) can be traced in the zone of conjunction of the NepaPeleduy dome with the Predpatom depression.

The deposits of the Khamakin productive interval are represented by uneven alternation of sandstone layers, gravelites, siltstones with argillite 
interlayers. Sandstones are very diverse in terms of lithological properties. For example, in some sections feldspar-quartz slightly sorted coarsegrained differences predominate, where large sand and gravelite fractions dominate. There are feldspath-quartz and quartz well-sorted medium and fine-grained sandstones in others. The rocks are cemented mainly by clay cement with chloritehydromicaceous composition, carbonatized in various degrees, salty, fractured.

The drilling data show that the Khamakin productive interval combines a series of formations differing in both thickness and area of distribution and in terms of their reservoir properties. An interval was formed in various alluvial and coastalmarine environments. This led to the presence in its composition of both poorly sorted gravelite sandstones and well-sorted, "tongue" shapes of sand bodies, appearance of kaolinite cement in sandstones. Lithological-facies heterogeneity and complexity of composition of rocks composing this interval increase near the zone of pinching out of the Khamakin productive interval. A clear tendency of deterioration of reservoir parameters of interval rocks is observed with an increase in their carbonate content.

The porosity of rocks of the Hamakin interval varies from 1.0 to $21 \%$, permeability varies in the range of $1-6000 \mathrm{mD}$. The reservoirs of IV class prevail.

Upper clay pack of the Upper-Parsh subsuite is a cap rock for the Khamakin productive interval. Its thickness in the northern and north-western parts of the interval of spreading region is $13-30 \mathrm{~m}$ and increases more than $80 \mathrm{~m}$ in the southeast direction. It is composed of argillites, silty mudstones of the hydrosilicate composition. There are siltstones passing into sandstones (from fiber type 2-10 cm), fine-grained clayish, with inclusions and cracks of anhydrite. Inclusions of pyrite are noted.

Gas deposits have been discovered at the Chayandinskoye and Talakanskoye fields within the regional zone. The maximum gas rates from rocks of the Khamakin interval were obtained in wells 321-63 and 321-48 - 770.6 and 642.6 thousand $\mathrm{m}^{3} /$ day, respectively.

Formation of the Khamakin interval of the Upper-Parsh suite is associated with the conditions for existence of a strongly dissected paleorelief. A feature of paleorelief is presence of steep slopes of a complex configuration in plan with a trend of falling from west to east and southeast. The direction of removal of clastic material determines features of the paleorelief structure.

According to modern ideas, deposits formed in a coastal zone partly in conditions of temporary flows, partly in conditions of beach.

A.B. Tarasenko [16] proposed a model of structure of layers of the sedimentary system of isolated shallow water for Khamakin time. The author believes that during Khamakin time on the territory of the Nepa-Botuoba anteclise sedimentation occured in the zone of isolated shallow water with a bar complex of deposits of the northeast direction. A decrease in sea level led to displacement of bar bodies towards the sea. Increase in removal of detrital material from land contributed to formation of a sandy beach. The beach gradually through the inner inactive lagoon area, in which clay deposits accumulated, passed into the moving part where alternating layers of clays, sands and siltstones formed. There were "patchwork sands" accumulated in the conditions of forebar variable wave hydrodynamics. The researcher made such conclusions on the basis of an optical microscopic study of rocks in thin sections, cores description materials and well logging data.

In the opinion of M.V. Lebedev [17, 18], the Khamakin facies series were accumulated on the southern slope of extensive paleoanteclise in subcontinental and coastal-marine sedimentation environments. The main factors that caused heterogeneity of the reservoir were transgressive pitching out of deposits at the slope of the paleoanteclise, lateral replacement of sandstones of the delta complexes by clay sediments of the coastal plains and shallow bays. We believe that 
the theory of conditions of sedimentation of the Khamakin interval, proposed by M.V. Lebedev $[17,18]$, is the most correct. That well describes revealed lithologic, facies and sedimentological features of these clastic deposits.

The Khamakin productive interval is lithologically represented by sandstones gray, medium and coarse grained, feldspar-quartz, crossbedded, with clay-anhydrite and clay-carbonate cement, which contains thin interlayers of green to gray and red to brown silty mudstones, gravelites. Total thickness of clastic deposits of the Khamakin interval within the research area changes from 20 to $100 \mathrm{~m}$ and more, increasing to the southeast. Gas inflow was obtained from the deposits of the Khamakin interval at the Chayandinskoye field.

Correlation and tracing of clastic rocks of the Khamakin interval revealed that the reservoirs of the Khamakin horizon are not traced in the section and in some places are split into two sub-horizons two productive layers of $\mathrm{Khm}-1$ and $\mathrm{Khm}-2$. Picking of two reservoirs is necessary in order to trace spatial distribution of the reservoirs in details, reveal regularities of quality of reserves and construct a structural framework for threedimensional geological modeling correctly. Cycles of layers Khm-1 and Khm-2 are different. Khm-1 corresponds to regressive cycle. Khm-2 corresponds to transgressive cycle.

We believe that conditions where Khm-1 deposits were formed are associated with wandering channels and embedded valleys for Khm-2 deposits. Fig. 7 shows delineated channel-like embedding in well 2 , which is clearly seen in the sections of the cube of pseudo impedances.

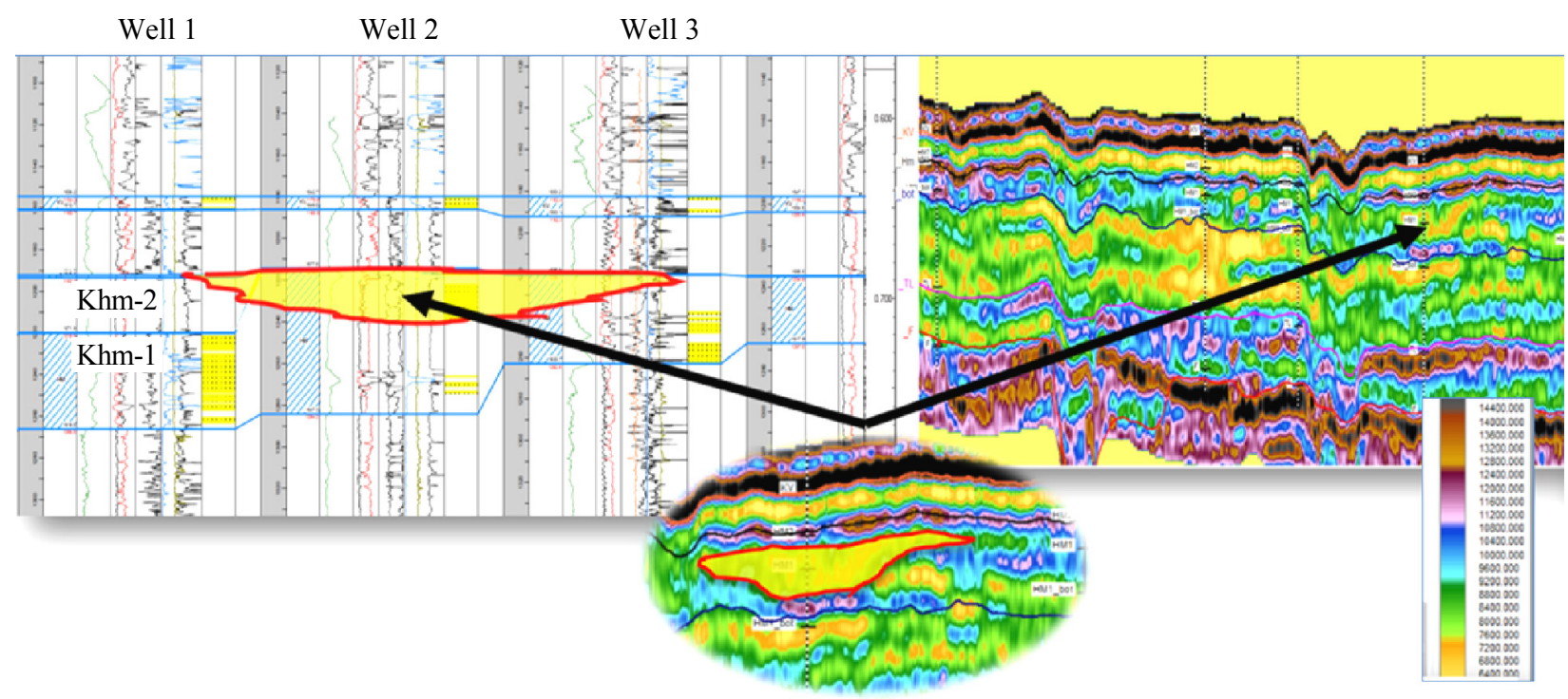

Fig. 7. An example of the allocation of erosion embedded valleys in the Late Khamakin period

FMI method was used in wells. That allowed based on the analysis of textural features by presence of sandstone with an admixture of gravelite material in the lower part of clastic cycles, presence of frequently appearing oblique layering and a double erosion surface to diagnose deposits as precipitations that were deposited in the conditions of wandering rivers.

Such conclusion was made based on sedimentological criteria of E.Yu. Baraboshkin [19].

\section{Use of AVO-analysis to study features of structure of productive deposits}

Function of amplitude (reflection) versus deletion (AVO (AVA)) is a technique used to obtain information about properties of host rocks and presence of hydrocarbon saturation in the reservoir [20-24]. During processing of seismic data, "angular samples" were obtained. Each trace is a sequence of signals with the same 
range of angles of incidence, summation of which gives a volume called the "angular sum". From the set of angular sums AVO attributes were calculated as

$$
\text { cubes - AVO - intercept }(A) \text {, }
$$

where $A$ is a value, proportional to the coefficient of reflection $R \mathrm{p}$ in case of normal incidence;

$$
\text { cube of gradients - AVO - gradient }(B),
$$

where $B$ is a value, proportional to the tangent of slope angle, that averages dependancy of $R\left(\sin ^{2} \theta\right)$, in set range of incident angles $\theta$;

cube "fluid-factor":

$$
\Delta F=\Delta V_{p} / V_{p}-1,16 V_{s} / V_{p} \cdot \Delta V_{s} / V_{s},
$$

where the coefficient of 1.16 of sandy-argillaceous rocks with reservoir water saturation leads to a value of $\Delta F$ to zero, which allows to predict gas saturation by increase in "fluid factor";

$$
\text { cube }\left(N_{f a r}-N_{\text {near }}\right) N_{f a r} \text {. }
$$

If a sandstone saturated with water is characterized by an acoustic impedance smaller than that of surrounding medium, and the impedance of a clastic reservoir saturated with hydrocarbons is even smaller, then sections of that attribute will contain anomalies with more contrast that previous attributes if thickness of differentiated by impedance layers is enough. When different angular sums are compared, the nature of dependence of energy of a reflected wave on an angle of incidence for individual seismic horizons is determined. Significant changes in amplitudes as a function of an angle of incidence represent a good indication of the possible presence of hydrocarbons.
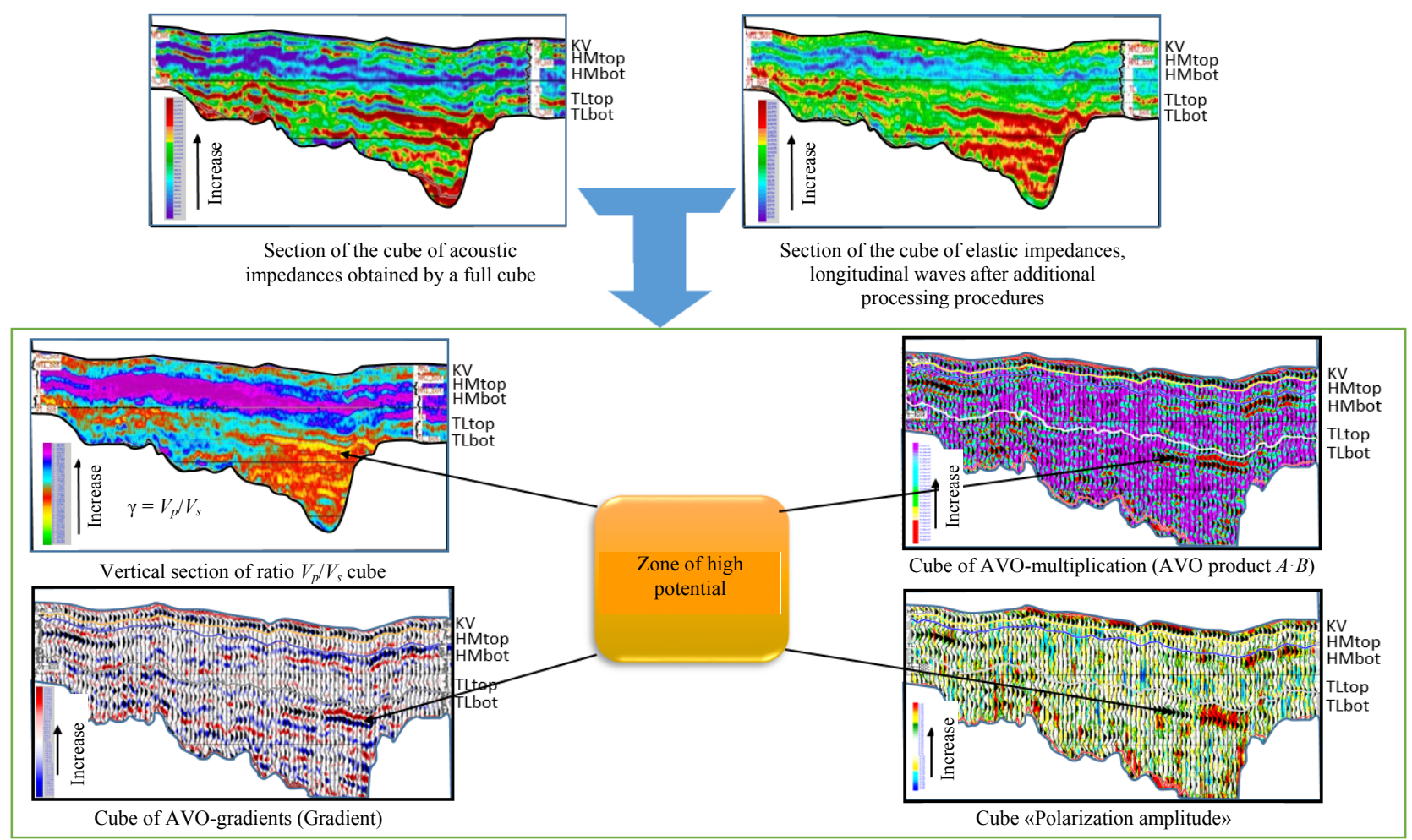

Fig. 8. Attribute characteristic of the productive part of the section: KV - Roof of the Botuobinsk formation; HMtop - roof of the Khamakin formation; HMbot - bottom of of the Khamakin formation; TLtop - roof of the Talakh formation; TLbot - bottom of of the Talakh formation

In classical formulation of the issue AVOtechnology is used to predict gas saturation of target objects. To assess reliability of information about attributes obtained by AVO- technology, gradient maps, productivity in the interval of occurrence of the Botuobinsk, Khamakin and Talakh horizons are calculated (Fig. 8). 
Experience shows that after careful selection of attributes obtained and compilation with each other it is possible to localize potential zones and recommend to drill exploration wells.

\section{Azimuth processing of seismic data to overcome geological challenges}

Note that the standard 3D seismic survey is able to solve a limited range of applied challenges. Therefore, the attention paid by specialists to technologies that are aimed to study anisotropy of properties of the section becomes understandable [20, 25-31].

Today, all four basic methods for studying anisotropy of properties of the geological section are used in practice of seismic exploration such as:

- a method based on the study of geometric attributes;

- azimuth velocity analysis;

- azimuth AVO-analysis (AVAZ);

- azimuth inversion.

The main purpose of azimuth processing is to obtain data characterizing direction of the "fast" and "slow" velocity vectors in the layer, and in the case of a successful analysis they allow forecasting prevailing direction of fracturing of rocks. To carry out such an analysis special processing is applied, which is used for wide-azimuth data. In order to preserve information on azimuths, special regularization is carried out with preservation of data on azimuths of removal. The data were divided into eight azimuth sectors of 45 degrees, time migration of Kirchhoff pre-stacking is performed on four sets of data into which opposing azimuth sectors were put together (0-45 and 180225 degrees, 45-90 degrees and 225-270 degrees etc.). According to migrated seismograms, a highresolution specification of migration velocities was carried out. Cubes of migration velocities are recalculated into interval velocities through the analytic transformation. Next, the interval velocity calculation along the target horizons in a narrow interval of $25 \mathrm{~ms}$ is performed. Obtained maps of interval velocities were used to calculate directions of "fast" and "slow" velocity at each common depth point using the "ellipse fitting" algorithm. As a result, maps of the direction of "fast" speed, interpreted as fracturing of rocks, were obtained for three horizons.

An example of a map of probable distribution of the direction of crack propagation, constructed on the basis of azimuth-velocity analysis of data, with the data of bedding measurements using FMI is presented next. Measurements of elements of the occurrence of cracks in one of wells showed that azimuth of bedding of cracks has a preferential direction of 140-150 degrees (south-east), and in the interval of the foundation of rocks the trend of cracks bedding varies by $80-100$ degrees. The analysis showed that good convergence was obtained between measurements of direction of crack propagation according to data of a downhole scanner and according to azimuth-velocity analysis performed (Fig. 9).

It should be noted that good convergence comparing bedding of fracturing in the interval of the productive part of the Vendian section is not the only result. Preliminary conclusion has been made according to which it is possible to evaluate big faults located near the well by a downhole scanner (see Fig. 9).

The main result of establishing convergence of well and seismic data is that we are able to identify features of development of fracture fields in space between wells.

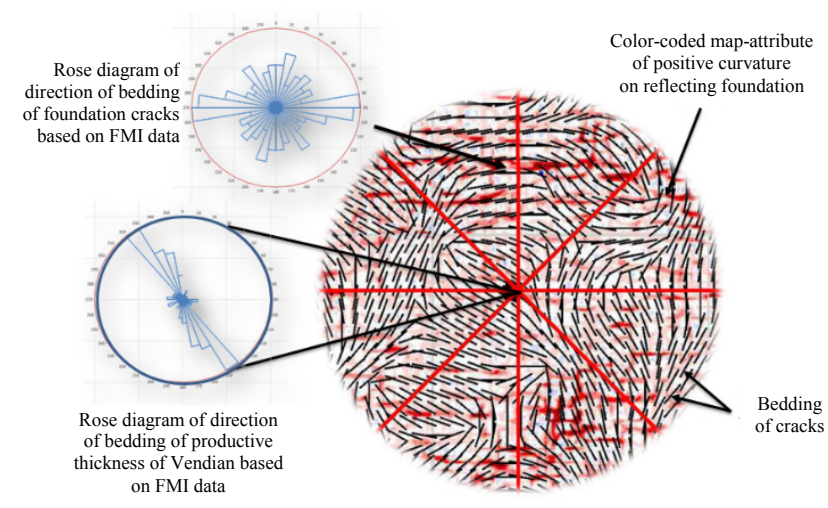

Fig. 9. Fragment of the map of probable distribution of the direction of the bedding of cracks, built on the basis of azimuth-velocity data analysis 


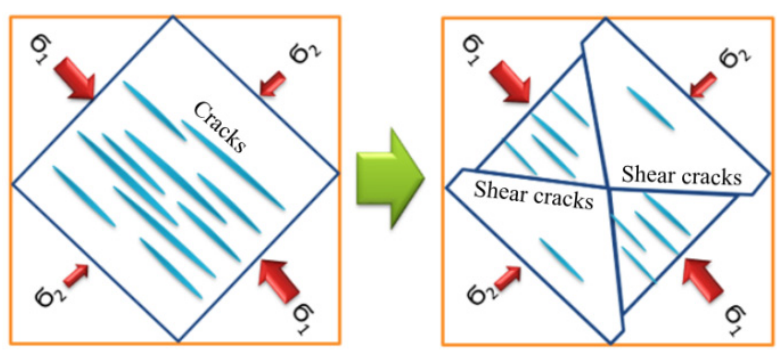

Fig. 10. Shear and tear cracks formed during the isotropic medium compression

The analysis and comparison of directions of crack propagation in a well and in space between them were performed. That was the basis for forecast of the main stresses directions. The main stresses have strike azimuths of 140-150 degrees (south-east) - 320-330 degrees (northwest), which allows planning to drill horizontal or inclined wells across the established bedding of the fracture system. In this case the direction is 240 degrees to south-west or 60 degrees to north-east. Shear cracks accompany tearing cracks, which occur during compression when the shear strength of the rock is exceeded.

\section{Conclusion}

It should be noted that during the seismic survey at the Chayadinskoye field it was possible to draw very important conclusions.

Based on results of processing and complex interpretation of seismic data of MOGT-3D works at the Chayandinskoye oil and gas condensate field, the most important information was obtained on the geological structure of deposits of the sedimentary cover and the productive part of the section. That allowed to significantly clarify the concept of structure of productive horizons and geological development of the given territory and make more accurate estimation of spatial distribution of reservoirs and reserves taking into account the new built structural and tectonic model. Data cubes that are as following were obtained: pseudo-acoustic impedances from a full multiplicity data cube, pseudo-gamma ray logging, elastic and shear impedances, densities and $V_{p} / V_{s}$, on AVO-technology (intercept, gradient, fluid factor, $\left.\lambda \rho, \mu \rho, Z_{p}, Z_{s}, R_{p}, R_{s}\right)$.

Note that used wide azimuthal observation system will correctly perform an analysis of azimuthal anisotropy of velocity characteristics of the section. Therefore, the conclusions are:

1. Results of treatment prove expediency of applying the technique in complex seismic and geological conditions of Eastern Siberia. It becomes real to use fracture prediction in oil exploration works.

2. We consider that important to continue the work on improving the field methodology aimed to increase geological information content of $3 \mathrm{D}$ seismic studies (including the refusal to group etc.).

That works are carried out in accordance with the program of experimental and methodological fieldwork of 2013, developed by specialists of INGEOSERVICE LLC and coordinated with Gazprom Geologorazvedka LLC.

\section{References}

1. Kreknin S.G., Pogretskii A.V., Krylov D.N., Trukhin V.Iu., Sitdikov N.R. Sovremennaia geologogeofizicheskaia model' Chaiandinskogo neftegazokondensatnogo mestorozhdeniia [Modern geological and geophysical model of the Chayandinskoye oil and gas condensate field]. Geologiia nefti $i$ gaza, 2016, no. 2, pp. 44-55.

2. Berzin A.G., Marsanova M.R., Ivanov I.S. O perspektivakh otkrytiia neftegazonosnogo basseina $\mathrm{V}$ podfundamentnykh otlozheniiakh Nepsko-Peleduiskogo svoda na iugo-zapade Respubliki Sakha (Iakutiia)
[On the prospects for the discovery of the oil and gas bearing basin in the subfundamental sediments of the Nepa-Peleduy arch in the southwest of the Republic of Sakha (Yakutia)]. Nauki o Zemle, 2014, II, available at: http://edu-science.ru/ (accessed: 14 January 2017).

3. Burova I.A., Kubetova N.L., Shostak K.V. Rasprostranenie osnovnykh solenosnykh tolshch $\mathrm{V}$ verkhnevendsko-nizhnekembriiskom osadochnom komplekse Zapadnoi Iakutii [Distribution of the main saliferous sequences in the Upper 
Vendian-Lower Cambrian sedimentary complex of Western Yakutia]. Neftegazovaia geologiia. Teoriia $i$ praktika, 2011, vol.6, no.4, available at: http://www.ngtp.ru/ rub/4/46_2011.pdf (accessed: 11 January 2017).

4. Fomin A.M., Moiseev S.A., Topeshko V.A. Talakhskii produktivnyi gorizont (usloviia formirovaniia, stroenie i perspektivy neftegazonosnosti) [Talakhsky productive horizon (formation conditions, structure and prospects of oil and gas potential)]. Interekspo Geo-Sibir'-2012: VIII Mezhdunarodnaia konferentsiia "Nedropol'zovanie. Gornoe delo. Novye napravleniia $i$ tekhnologii poiska, razvedki i razrabotki mestorozhdenii poleznykh iskopaemykh”. Novosibirsk, 2012, vol.2, pp.14-18.

5. Fomin A.M., Moiseev S.A. Stroenie i usloviia formirovaniia botuobinskogo neftegazonosnogo gorizonta na severo-vostoke Nepsko-Botuobinskoi anteklizy [The structure and conditions of the formation of the Botuobinsk oil and gas bearing horizon in the north-east of the Nepa-Botuoba anteclise]. Geologiia $i$ mineral'nosyr'evye resursy Sibiri, 2014, no.2, pp.60-65.

6. Shemin G.G. Tektonicheskie predposylki perspektiv neftegazonosnosti Nepsko-Botuobinskoi anteklizy [Tectonic preconditions for the prospects of the oil and gas bearing of the Nepa-Botuoba anteclise]. Novye dannye po geologii i neftegazonosnosti Leno-Tungusskoi provintsii. Novosibirsk, Sibirskii nauchno-issledovatel'skii institut geologii, geofiziki i mineral'nogo syr'ia, 1982, pp.40-47.

7. Shemin G.G. Geologiia i perspektivy neftegazonosnosti venda i nizhnego kembriia tsentral'nykh raionov Sibirskoi platformy (Nepsko-Botuobinskaia, Baikitskaia antekliza i Katangskaia sedlovina) [Geology and prospects of oil and gas content of the Vendian and Lower Cambrian of the central regions of the Siberian Platform (Nepsko-Botuobinskaya, Baikit anteclise and Katangskaya saddle)]. Novosibirsk, Institut geologii i geofiziki Sibirskogo otdeleniia Akademii nauk SSSR, 2007, 467 p.

8. Shemin G.G., Fortunatova N.K. Detal'naia korreliatsiia vendsko-nizhnekembriiskikh podsolevykh otlozhenii Predpatomskogo regional'nogo progiba i smezhnoi territorii Nepsko-Botuobinskogo anteklizy (Sibirskaia platforma) [Detailed correlation of Vendian Lower Cambrian subsalt deposits of Predpatom regional trough and the adjacent area of the Nepa-Botuoba anteclise (Siberian platform)]. Geologiia nefti $i$ gaza, 2012, no.4 (12), pp.8-25.
9. Kosachuk G.P., Burakova S.V., Butochkina S.I., Mel'nikova E.V., Budrevich N.V. K voprosu o formirovanii neftianykh zalezhei (otorochek) mestorozhdenii Nepsko-Botuobinskoi anteklizy [To the question of the formation of oil deposits (rims) of the deposits of the Nepa-Botuobinsk anteclise]. Vesti gazovoi nauki, 2013, no.5(16), pp.114-123.

10. Postnikova O.V., Fomicheva L.N., Solov'eva L.V., Poshibaeva V.V., Konoval'tseva E.S. Prirodnye rezervuary rifei-vend-kembriiskogo osadochnogo basseina iuga Sibirskoi platformy: osobennosti stroeniia i zakonomernosti razmeshcheniia [Natural reservoirs of the Riphean-Vendian-Cambrian sedimentary basin of the south of the Siberian platform: features of the structure and regularities of location]. Geologiia nefti i gaza, 2010, 6, pp.54-64.

11. Ryzhov A.E. Tipy i svoistva terrigennykh kollektorov venda Chaiandinskogo mestorozhdeniia [Types and properties of terrigenous reservoirs of the Vendian of the Chayandinskoye deposit]. Vesti gazovoi nauki, 2013, no.1 (12), pp.145-160.

12. Berzin A.G., Safronov A.F., Sitnikov V.S. Evoliutsiia protsessov tektogeneza i osadkonakopleniia $\mathrm{v}$ geologicheskoi istorii Vostoka Sibirskoi platformy [Evolution of the processes of tectogenesis and sedimentation in the geological history of the East of the Siberian Platform]. Regional'naia geologiia mestorozhdeniia poleznykh iskopaemykh. Materialy mezhdunarodnoi konferentsii "Gornogeologicheskoe obrazovanie v Sibiri”. Tomsk, 2001, vol.1, pp. 18-22.

13. Kolotushchenko L.D. Osnovnye produktivnye gorizonty Botuobinskogo neftegazonosnogo raiona [The main productive horizons of the Botuobinsk oil and gas bearing area]. Ph. D thesis. Iakutsk, 1984, 184 p.

14. Ivchenko O.V. Zavisimost' udel'noi produktivnosti terrigennykh kollektorov ot ikh fatsial'noi prinadlezhnosti na primere severnogo bloka botuobinskogo gorizonta Chaiandinskogo mestorozhdeniia [Dependence of the specific productivity of terrigenous reservoirs on their facial affiliation by the example of the northern block of the Botuobinsk horizon of the Chayandinskoye deposit]. Sbornik nauchnykh statei aspirantov i soiskatelei OOO “Gazprom VNIIGAZ”. Moscow, Gazprom VNIIGAZ, 2013, pp.42-50.

15. Lebedev M.V., Moiseev S.A., Topeshko V.A., Fomin A.M. Stratigraficheskaia skhema terrigennykh otlozhenii venda severo-vostoka Nepsko-Botuobinskoi anteklizy [Stratigraphic scheme of the terrigenous deposits 
of the Vendian of the Northeast of the Nepa-Botuoba anteclise]. Geologiia i geofizika, 2014, 5, pp.874-890.

16. Tarasenko A.B. Litologo-geneticheskii analiz vendskogo terrigennogo kompleksa Nepsko-Botuobinskoi anteklizy [Lithological and genetic analysis of the Vendian terrigenous complex of the Nepa-Botuoba anteclise]. VII Vserossiiskoe litologicheskoe soveshchanie, 2013, pp.198-202.

17. Lebedev M.V. Stratigraficheskaia skhema terrigennykh otlozhenii venda severo-vostoka NepskoBotuobinskoi anteklizy [Stratigraphic scheme of the terrigenous deposits of the Vendian of the Northeast of the Nepa-Botuoba anteclise]. Geologiia i geofizika, 2014, vol.55, no.5-6, pp.874-890.

18. Lebedev M.V. Teoreticheskie osnovy postroeniia fatsial'nykh modelei osadochnykh neftegazonosnykh basseinov i opyt fatsial'nogo modelirovaniia terrigennykh otlozhenii venda severo-vostoka Nepsko-Botuobinskogo NGO (Sibirskaia platforma) [Theoretical basis for the construction of facial models of sedimentary oil and gas basins and the experience of facies modeling of terrigenous deposits of the Vendian of the Northeast of the Nepa-Botuoba NGO (Siberian Platform)]. Doctor's degree dissertation. Tiumen', 2015, $281 \mathrm{p}$.

19. Baraboshkin E.Iu. Prakticheskaia sedimentologiia (terrigennye kollektory) [Practical sedimentology (terrigenous reservoir)]. Tomsk, Tsentr professional'noi podgotovki spetsialistov neftegazovogo dela TPU, 2007, $155 \mathrm{p}$.

20. Kozlov E.A. Modeli sredy v razvedochnoi seismologii [Models of environment in exploration seismology]. Tver', 2006, $480 \mathrm{p}$.

21. Castagna J.P., Bazle M.L., Kan T.K. Rock physics The link between rock properties and AVO response. Offset-dependent reflectivity - Theory and practice of AVO analysis. Eds. J.P. Castagna, M.M. Backus. SEG, 1993, pp.135-171.
22. Dong W. AVO detectability against tuning and stretching artifacts. Geophysics, 1999, vol.64, no.2, pp.494-503. DOI: $10.1190 / 1.1444555$

23. Goodway B., Chen T., Downton J. Rock parameterization and AVO fluid detection using Lame petrophysical factors $-\lambda, \mu$ and $\lambda \varrho, \mu \varrho$. EAGE, 1999, Expended Abstracts, pp. 6-51.

24. Swan H.W. Properties of direct hydrocarbon indicators. Offset-dependent reflectivity - Theory and practice of AVO analysis. Eds. J.P. Castagna, M.M. Backus. seg, 1993, pp.78-92. DOI: 10.1190/1.9781560802624.ch1

25. Cambois G. AVO inversion and elastic impedance. SEG, 2000, Expended Abstracts, pp. 1-4.

26. Connolly P. Elastic impedance. The0 Leading Edge, 1999, vol.18, no.4, pp.438-452. DOI: $10.1190 / 1.1438307$

27. Debski W., Tarantola A. Information on elastic parameters obtained from the amplitudes of reflected waves. Geophysics, 1995, vol.60, no.5, pp.1426-1436. DOI: $10.1190 / 1.1443877$.

28. Gardner G.H.F., Gardner L.W., Gregory A.R. Formation velocity and density - The diagnostic basics for stratigraphic traps. Geophysics, 1974, vol.39, no.6, pp.1603-1615. DOI: 10.1190/1.1440465

29. Garotta R., Granger P.-Y., Dariu H. Elastic parameter derivations from multi-component data. SEG, 2000, Expended Abstracts, pp.154-157.

30. Thomsen L. Weak elastic anisotropy. Geophysics, 1986, vol.51, no.10, pp.1954-1966. DOI: 10.1190/1.1442051

31. VerWest B., Masters R. and Sena A. Elastic impedance inversion. SEG, 2000, Expanded Abstracts, pp.150-152.

\section{Библиографический список}

1. Современная геолого-геофизическая модель Чаяндинского нефтегазоконденсатного месторождения / С.Г. Крекнин, А.В. Погрецкий, Д.Н. Крылов, В.Ю. Трухин, Н.Р. Ситдиков // Геология нефти и газа. 2016. - № 2. - С. 44-55.

2. Берзин А.Г., Марсанова М.Р., Иванов И.С. $\mathrm{O}$ перспективах открытия нефтегазоносного бассейна в подфундаментных отложениях Непско-Пеледуйского свода на юго-западе Республики Саха (Якутия) [Электронный ресурс] / Международный научный институт «Educatio» // Науки о Земле. - 2014. -
II. - URL: http://edu-science.ru/ (дата обращения: 14.01.2017).

3. Бурова И.А., Кубетова Н.Л., Шостак К.В. Распространение основных соленосных толщ в верхневендско-нижнекембрийском осадочном комплексе Западной Якутии [Электронный ресурс] // Нефтегазовая геология. Теория и практика. - 2011. T. 6, № 4. - URL: http://www.ngtp.ru/rub/4/46_2011.pdf (дата обращения: 11.01.2017).

4. Фомин А.М., Моисеев С.А., Топешко В.А. Талахский продуктивный горизонт (условия формиро- 
вания, строение и перспективы нефтегазоносности) // Интерэкспо Гео-Сибирь-2012: VIII Междунар. конф. «Недропользование. Горное дело. Новые направления и технологии поиска, разведки и разработки месторождений полезных ископаемых». Новосибирск, 2012. - Т. 2. - С. 14-18.

5. Фомин А.М., Моисеев С.А. Строение и условия формирования ботуобинского нефтегазоносного горизонта на северо-востоке Непско-Ботуобинской антеклизы // Геология и минерально-сырьевые ресурсы Сибири. - 2014. - № 2. - С. 60-65.

6. Шемин Г.Г. Тектонические предпосылки перспектив нефтегазоносности Непско-Ботуобинской антеклизы // Новые данные по геологии и нефтегазоносности Лено-Тунгусской провинции / Сиб. науч.-исслед. ин-т геологии, геофизики и минерального сырья. - Новосибирск, 1982. - С. 40-47.

7. Шемин Г.Г. Геология и перспективы нефтегазоносности венда и нижнего кембрия центральных районов Сибирской платформы (НепскоБотуобинская, Байкитская антеклиза и Катангская седловина) / Ин-т геологии и геофизики Сибирского отделения Академии наук СССР. - Новосибирск, 2007. - 467 с.

8. Шемин Г.Г., Фортунатова Н.К. Детальная корреляция вендско-нижнекембрийских подсолевых отложений Предпатомского регионального прогиба и смежной территории Непско-Ботуобинского антеклизы (Сибирская платформа) // Геология нефти и газа. - 2012. - № 4 (12). - С. 8-25.

9. К вопросу о формировании нефтяных залежей (оторочек) месторождений Непско-Ботуобинской антеклизы / Г.П. Косачук, С.В. Буракова, С.И. Буточкина, Е.В. Мельникова, Н.В. Будревич // Вести газовой науки. - 2013. - № 5 (16). - С. 114-123.

10. Природные резервуары рифей-вендкембрийского осадочного бассейна юга Сибирской платформы: особенности строения и закономерности размещения / О.В. Постникова, Л.Н. Фомичева, Л.В. Соловьева, В.В. Пошибаева, Е.С. Коновальцева // Геология нефти и газа. - 2010. - 6. - С. 54-64.

11. Рыжов А.Е. Типы и свойства терригенных коллекторов венда Чаяндинского месторождения // Вести газовой науки. - 2013. - № 1 (12). - С. 145-160.

12. Берзин А.Г., Сафронов А.Ф., Ситников В.С. Эволюция процессов тектогенеза и осадконакопления в геологической истории востока Сибирской платформы // Региональная геология месторождения полезных ископаемых: материалы междунар. конф.
«Горно-геологическое образование в Сибири». Томск, 2001. - Т. 1. - С. 18-22.

13. Колотущенко Л.Д. Основные продуктивные горизонты Ботуобинского нефтегазоносного района: дис. ... канд. геол.-мин. наук. - Якутск, 1984. - 184 с.

14. Ивченко О.В. Зависимость удельной продуктивности терригенных коллекторов от их фациальной принадлежности на примере северного блока ботуобинского горизонта Чаяндинского месторождения // Сб. науч. ст. аспирантов и соискателей ООО «Газпром ВНИИГАЗ». - М.: Газпром ВНИИГАЗ, 2013. - С. 42-50.

15. Стратиграфическая схема терригенных отложений венда северо-востока Непско-Ботуобинской антеклизы / М.В. Лебедев, С.А. Моисеев, В.А. Топешко, А.М. Фомин // Геология и геофизика. 2014. - 5. - C. 874-890.

16. Тарасенко А.Б. Литолого-генетический анализ вендского терригенного комплекса НепскоБотуобинской антеклизы // VII Всероссийское литологическое совещание. - Новосибирск, 2013. C. 198-202.

17. Лебедев М.В. Стратиграфическая схема терригенных отложений венда северо-востока НепскоБотуобинской антеклизы // Геология и геофизика. 2014. - Т. 55, № 5-6. - С. 874-890.

18. Лебедев М.В. Теоретические основы построения фациальных моделей осадочных нефтегазоносных бассейнов и опыт фациального моделирования терригенных отложений венда северо-востока НепскоБотуобинского НГО (Сибирская платформа): дис. ... д-ра геол.-мин. наук. - Тюмень, 2015. - 281 с.

19. Барабошкин Е.Ю. Практическая седиментология (терригенные коллекторы). - Томск: Центр профессиональной подготовки специалистов нефтегазового дела ТПУ, 2007. - 155 с.

20. Козлов Е.А. Модели среды в разведочной сейсмологии. - Тверь, 2006. - 480 с.

21. Castagna J.P., Bazle M.L., Kan T.K. Rock physics the link between rock properties and AVO response // Offsetdependent reflectivity - Theory and practice of AVO analysis / Eds. J.P. Castagna, M.M. Backus. - SEG, 1993. - P. 13-171.

22. Dong W. AVO detectability against tuning and stretching artifacts // Geophysics. - 1999. - Vol. 64, № 2. P. 494-503. DOI: 10.1190/1.1444555

23. Goodway B., Chen T., Downton J. Rock parameterization and AVO fluid detection using Lame petrophysical factors $-\lambda, \mu$ and $\lambda \varrho, \mu \varrho / /$ EAGE. -1999 . Expanded Abstracts. - P. 6-51. 
24. Swan H.W. Properties of direct hydrocarbon indicators // Offset-dependent reflectivity - theory and practice of AVO analysis / Eds. J.P. Castagna, M.M. Backus. - SEG, 1993. - P. 78-92. DOI: 10.1190/1.9781560802624.ch1

25. Cambois G. AVO inversion and elastic impedance // SEG. - 2000. - Expanded Abstracts. - P. 1-4.

26. Connolly P. Elastic impedance // The Leading Edge. 1999. - Vol. 18, № 4. - P. 438-452. DOI: 10.1190/1.1438307

27. Debski W., Tarantola A. Information on elastic parameters obtained from the amplitudes of reflected waves // Geophysics. - 1995. - Vol. 60, № 5. - P. 14261436. DOI: $10.1190 / 1.1443877$
28. Gardner G.H.F., Gardner L.W., Gregory A.R. Formation velocity and density - the diagnostic basics for stratigraphic traps // Geophysics. - 1974. Vol. 39, № 6. - P. 1603-1615. DOI: 10.1190/1.1440465

29. Garotta R., Granger P.-Y., Dariu H. Elastic parameter derivations from multi-component data // SEG. 2000. - Expanded Abstracts. - P. 154-157.

30. Thomsen L. Weak elastic anisotropy // Geophysics. - 1986. - Vol. 51, № 10. - P. 1954-1966. DOI: $10.1190 / 1.1442051$

31. VerWest B., Masters R., Sena A. Elastic impedance inversion // SEG. - 2000. - Expanded Abstracts. - P. 150-152.

Please cite this article in English as:

Davydov A.V., Pogretckii A.V., Smirnov O.A., Lukashov A.V., Pravdukhin A.P., Kurchikov A.R., Borodkin V.N. Chayandinskoye field is the project of new technologies implementation in East Siberia. Perm Journal of Petroleum and Mining Engineering, 2017, vol.16, no.2, pp.113-128. DOI: 10.15593/2224-9923/2017.2.2

Просьба ссылаться на эту статью в русскоязычных источниках следующим образом:

Чаяндинское месторождение - проект внедрения новых технологий в Восточной Сибири / А.В. Давыдов, А.В. Погрецкий, О.А. Смирнов, А.В. Лукашов, А.П. Правдухин, А.Р. Курчиков, В.Н. Бородкин // Вестник Пермского национального исследовательского политехнического университета. Геология. Нефтегазовое и горное дело. - 2017. - Т. 16, № 2. - С. 113-128. DOI: $10.15593 / 2224-9923 / 2017.2 .2$ 